\title{
The Deadly Serious Causes of Legitimate Rebellion: Between the Wrongs of Terrorism and the Crimes of War
}

\author{
Christopher J. Finlay ${ }^{1}$ (D)
}

Published online: 11 July 2017

(C) The Author(s) 2017. This article is an open access publication

\begin{abstract}
This article challenges the tendency exhibited in arguments by Michael Ignatieff, Jeremy Waldron, and others to treat the Law of Armed Conflict (LOAC) as the only valid moral frame of reference for guiding (and judging) armed rebels with just cause. To succeed, normative language and principles must reflect not only the wrongs of 'terrorism' and war crimes, but also the rights of legitimate rebels. However, these do not always correspond to the legal privileges of combatants. Rebels are often unlikely to gain belligerent recognition and might sometimes have strong moral reasons to exceed the rights of regular combatants. Where this gives rise to tensions between morality and the LOAC, a decision is needed to determine which to follow. Setting aside the idea of (a) suppressing just war theory altogether in favour of a more purely regulatory approach to war and (b) reforming law in the direct light of moral theory, I question the attempt by Waldron (among others) (c) to argue that moral weight of the legal conventions at the heart of the LOAC trump any moral reasons there might be for breaching them. Even if noncombatant immunity is, as Waldron suggests, a deadly serious convention, I argue that war is justified only if pursued for the sake of deadly serious causes which may even be serious enough to oblige agents to break the law. A political theory of the ethics of war is needed (d) to mediate between the moral and legal in such cases where they cannot be reconciled directly.
\end{abstract}

Keywords Rebellion - Terrorism - Deadly serious conventions · Non-combatant immunity · War crimes · Just war theory · Michael Ignatieff · Jeremy

Waldron

An earlier draft of this paper was presented at the annual meeting of the International Studies Association in Atlanta, Georgia, March 2016. I would like to thank my fellow panellists at the conference, Pål Wrange, Jens Bartelson, and Jonathan Parry, for discussion during the conference and both Jens and Alejandro Chehtman for written comments afterwards.

Christopher J. Finlay

cfinlay@usa.net

1 University of Birmingham, Birmingham, UK 


\section{Introduction}

The Law of Armed Conflict ('LOAC' below) serves a variety of interrelated purposes. Its first is heuristic, providing action-guiding rules through which combatants, for instance, can determine which people and things they may direct violence against, which are immune from attack, and so on (Haque 2014). Second, it contributes to the definition of war crimes: 'War crimes generally are defined as serious violations of the laws and customs of war,' as Adil Ahmad Haque writes, so, '[i]t follows that nothing can be a war crime that is not also a violation of the laws of war' (Haque 2014, 92). The LOAC thus underpins part of international criminal law but it is also, in return, supported by criminalization insofar as the risk of legal penalties for war crimes incentivizes compliance with the rules. Third, and less directly, the LOAC defines one of the triggers for military intervention under the Responsibility to Protect. Finally, the LOAC provides a common normative vocabulary through which to form a view in public-political debate on the conduct of particular wars (Kennedy 2006, 7-8). It does so by reference to its first three functions. My concern is chiefly with the question of whether the LOAC can perform this fourth function adequately when debate turns to rebels or revolutionaries in civil conflicts.

A number of philosophers argue that it can. Michael Ignatieff maintains (2002) that if rebels are truly forced to resort to arms in order to defeat oppression, then they must adhere to the LOAC and especially to non-combatant immunity (NCI). Directly attacking civilian targets is one way of violating this principle. Another, as Tamar Meisels argues (2008, Chapter 4), is to use irregular methods of warfare that fail to distinguish one's fighters by means of clearly visible insignia and spatial separation. Jeremy Waldron's argument that NCI is a 'deadly serious convention' that binds combatants absolutely, regardless of the putative culpability of some civilians, is a further contribution (2010). In general, on this view, in cases where the moral wrongs identified with 'terrorism' are not viewed simply as criminal violence prosecutable under domestic law, they equate to a subset of the crimes of war (Ignatieff 2002, 1152-3).

I disagree, however, with this line of thinking. I argue that the LOAC ought to be seen as just one part of a more comprehensive approach to the problem that I call the 'political theory of the ethics of armed conflict'. My case is developed through three claims. First, the LOAC doesn't reflect the normative complexities of non-state political violence comprehensively enough or with sufficient nuance and suppleness to be able to act as sole guide for public debate about the ethics of rebellion. Second, I argue that the legitimacy of the LOAC as a 'moral frame of reference' (Ignatieff 2002, 1155) is threatened by what it excludes (morally justifiable actions that are nevertheless legally problematic), especially when this is juxtaposed with some of the things it includes (legally licensed violence that is morally problematic). Third, to stabilize the LOAC as a frame of reference for political debate, I argue that it is necessary to find a way to interpret it as part of a wider normative field that also includes the moral perspective of just war theory. ${ }^{1}$ This can't, however, be achieved either by reducing just war theory to the LOAC or vice versa. Acute conflicts arise between morality and law when adhering to the 'deadly serious convention' (Waldron 2010) at the heart of the LOAC stands in the way of satisfying a moral obligation to fight effectively for what I call 'deadly serious causes.' In such cases, I grant that law must often trump morality, but argue equally that it must be possible for morality sometimes to trump law. Instead of attempting to reconcile or simply subordinate one to the other, divergences

1 Sometimes the term 'just war theory' is used in a sense that encompasses international law but, like Kai Draper, I shall use the term in the 'traditional moral sense' (2016, 2 n. 1). 
between the perspectives of law and just war theory therefore call for a third, political perspective on the normative field from which to mediate between them.

The argument unfolds as follows. In Sect. 2, I argue that the rights attributable to rebels in the moral perspective of just war theory don't readily map onto the LOAC. In Sect. 3, I turn to the question of how we ought to relate law to morality, given the differences and tensions between them that I identify, focusing particularly on Waldron's argument for the supremacy of law. Section 4 then concludes by arguing that the respect owed to both law and morality demands that we adopt a political perspective within which to mediate between them and decide how best to apply them in concrete political contexts.

\section{War Crimes, Warlike Crimes, and Criminal Wars}

As I intend it, the term 'rebellion' encompasses both uprisings that aim at more limited goals such as a change of government and revolts that have the 'revolutionary' aim of radical change to a society, the state or ruling authority, or a state's territorial range. What I will call the 'Rebel Principle' holds that rebellion must be justifiable in some imaginable circumstances of acute social and political oppression and is likely to warrant the use of force in a subset of permissible cases. I assume there is quite a wide consensus on this principle (Dobos 2011; Biggar 2013, 393). But my claim is that, if we work out the principle's moral consequences and delineate the possible contours of a 'just armed rebellion,' they will run into tension with the LOAC on a series of important matters. ${ }^{2}$ Three types of mismatch can arise: between things legally prohibited under the LOAC but which are morally permissible or, as I'll argue below, morally justified or even commanded (mala prohibita but not in se); between things that are legally permitted but that are morally prohibited (mala in se but not mala prohibita); and between actions that are morally permitted or required but that the LOAC doesn't license by bestowing privileges or immunities necessary for a legal permission. I will begin with the latter.

\subsection{Illegal but Legitimate Rebels: Deep Morality Versus Deep Law}

Let's consider two possibilities that a theory of justified rebellion will warrant but which are likely to pose the privileges problem:

(1) Incipient revolt Persistent human rights violations by a regime domestically render it liable to resistance. Popular demonstrations are crushed, but peaceful protest is then followed by the beginnings of an armed rebellion.

(2) Victorious aggressors A successful act of international aggression results in morally unjust annexation of formerly independent territory to a foreign power. The people of that territory are profoundly opposed to their new rulers.

In both types of case resistance might be morally justifiable, perhaps initially through the exercise of widely recognized civil rights. Moreover, opponents of the regime would have a basic right of self- and other-defence while doing so against anyone wrongfully threatening them. And, in some circumstances, this might extend to a more organized form

\footnotetext{
${ }^{2}$ For the method of thinking through the implications of a right of revolution from the perspective of the rebels and then considering the consequences for international actors and international law, see Allen Buchanan's path-breaking article, Buchanan (2013). My intellectual debt to Buchanan's work will be obvious here and in Finlay (2017).
} 
of armed resistance of the sort associated with just war, where the right of the rebellious population to defence as a whole warrants a use of force against targets that exceeds what would be mandated by the ethics of individual self-defence alone. So attacks might be permitted - as they are in any war-against unsuspecting military targets, retreating soldiers, and others who pose no literally imminent threat considered as individuals. The reasons why such actions might be morally permissible in war raise questions that I address elsewhere but that go beyond the scope of this paper. For now, I'll simply assume that what is generally regarded as morally justifiable for combatants to do in a just war between two states is also morally justifiable when carried out under the auspices of a legitimate rebel leadership and for a just cause (subject to some other ad bellum requirements) (Finlay 2015).

At first glance, this might seem unproblematic from a legal perspective. But that is only until we ask at what point those who act as combatants on behalf of a legitimate rebellion of either kind may expect to be granted (and recognized as bearing) the privileges of belligerency. In just war theory, the in bello principle of discrimination that would apply once the rebels had satisfied the jus ad bellum would not only prohibit certain kinds of tactic - for instance, those aiming directly at innocent civilians - but would also license the use of force against opposing combatants. Or, alternatively, we might see it as reflecting a prior privileging of rebel defenders in this regard. This privilege is activated as soon as those ad bellum conditions have been satisfied. From the perspective of the LOAC, however, things are quite different and much more complicated.

Regardless of whether they have just cause, rebels are likely to face a number of unattractive possibilities prior to any chance of gaining recognition as privileged combatants. First, they might simply be treated after the fashion of classical public international law which defines 'rebellion' as an internal problem that states may address purely as a matter of policing and domestic security. The legal status of 'rebel,' in this framework, mandates force by the government but bestows no belligerent privileges on its opponents. Worse, it also permits domestic regimes to seek assistance from other states in the form of loans and arms (Doyle 2015,37-8). So, rather than adopting a stance of neutrality with regard to the opposing parties as they might do upon recognizing the conflict as a civil war, third party states viewing it as a rebellion are permitted to take the side of the incumbent regime (but are forbidden from assisting the rebels) (see Richard Falk cited in Cullen 2010, 9).

Under current international law, a second possibility arises once the conflict between rebels and the state/occupier reaches a certain scale, which is to recognize it as a condition of 'armed conflict' and therefore as subject to International Humanitarian Law (IHL). ${ }^{3}$ However, even setting to one side the problem of specifying the threshold above which the change in conflict status occurs, such cases face another more fundamental difficulty. While IHL introduces the possibility that parties engaged in the conflict may be held accountable for what it defines as 'war crimes,' it doesn't automatically imply that parties who were unprivileged before a condition of armed conflict was recognized are privileged afterwards. From the rebel perspective, in fact, applying the LOAC arguably renders the legal predicament faced by rebel combatants more precarious rather than less. Once it is in force, they can not only be charged domestically with 'murder' for all killing (even for

\footnotetext{
3 On belligerent occupation, see Rogers (2012, 240). Protracted fighting might constitute an 'international armed conflict' if the rebellion is against colonial rule, alien occupation, or a domestic racist regime under Additional Protocol I (1977) to the Geneva Conventions (1949) or as a 'non-international armed conflict' if conducted between the state and non-state dissident forces (or, indeed, between multiple non-state forces) (Additional Protocol II).
} 
what are, morally speaking, 'discriminate' acts of war) but may also be charged with 'war crimes' for actions breaching the principles of discrimination and proportionality as well as being subject to additional legal obligations specified by IHL. War crimes are widely held to be subject to universal jurisdiction and those faced with such charges do not benefit from a statute of limitations (Solis 2010, 303, 307).

In fact, according to what Jens David Ohlin calls the 'orthodox' view, rebels never gain privileged status under international law (Ohlin 2015, 338, 343). Be that as it may, rebels can be recognized as privileged belligerents when states choose to do so. But, as Anthony Cullen writes, when it became part of the repertoire of state practice in the nineteenth century, this granting of 'recognition of belligerency' was 'generally conceived of as an inherently political act [...] that concerned first and foremost the executive of a state and could not therefore be determined by a court of law without the court conforming to the position adopted by its government' $(2010,17)$. So, once it was accepted that there was a de facto civil war, it was at the discretion of the threatened government to determine whether captured domestic enemies be granted treatment as prisoners of war rather than continuing to be punished as 'murderers' for use of lethal force against state soldiers (in addition to such crimes of treason or similar as they may be subject to under domestic law). ${ }^{4}$

One other possibility is that rebels might be able to claim belligerent privileges independently of decisions taken by their enemies, provided they satisfy functional criteria of combatancy. Ohlin argues that these criteria are implicit in what he calls the 'deep' logic of the LOAC, being carried over implicitly into the present, post-war legal era from those components of classical public international law that it hasn't explicitly superseded. Once any force-be it directed by a state or by non-state parties-satisfies five conditions, then those using it gain combat privileges 'independent[ly] of formal political legitimacy' or the decisions of other parties: "[t]he requirements include: (a) a command structure with soldiers "commanded by a person responsible for his subordinates," (b) the wearing of a "fixed distinctive sign recognizable at a distance," (c) carrying arms openly, and (d) conducting operations "in accordance with the laws and customs of war"' (Ohlin 2015, 346). Another basis might be control of territory: once rebels secure a significant part of a contested state, their conflict is more likely to be recognized by third parties as a dispute between two state-like entities rather than a purely domestic disorder. Such cases are more readily assimilated to the paradigmatic picture of two states at war internationally (see, e.g., the Prizes Cases (1862) cited in Cullen 2010, 15). And finally, those who rebel against what they regard as 'colonial domination and alien occupation and against racist régimes in the exercise of their right of self-determination' (sometimes referred to as 'CAR conflicts') might hope to claim recognition as belligerents in cases that Additional Protocol I situates under the rubric of international armed conflicts (Additional Protocol 1, article 1.4).

None of these, however, solves the problem with which I began. This is because, on the one hand, it is still possible for cases of justified armed resistance to occur that fall below the relevant thresholds, are refused recognition by states, and are as yet unable to satisfy functional or formal criteria due to the incipient stage of their revolt. In the case of CAR conflicts, moreover, international recognition is contingent on states endorsing the

\footnotetext{
4 The possibility of punishing rebels even after such a war remained available to victorious governments: Neff (2005), 257-8. On humanitarian motives for recognizing belligerency domestically, see Cullen (2010), 16 (and, on the possibility of treating rebels as 'ordinary criminals,' see p. 56); on state interests as motives, see Neff (2005), 257-8; and on treason, see Ohlin (2015), 358-9. On the notion of 'war treason,' see Walzer (1977), 177.
} 
substantive justice of the rebels' cause which is unlikely and the CAR categories in any case exclude cases of rebellion against purely domestic, non-racist oppressors. Worse, while this means that various cases in which organized armed force is justified from a just war perspective will fall outside the normative scope of the LOAC, the formal or functional criteria that admit some such cases also license others that fall outside the moral range of just war theory. Consider the following:

(3) Fascist rebels with state-like capabilities There might be no justice-based grounds for recognizing the rebels as a belligerent party but their numbers, command of territory, or ability to satisfy functional requirements support the view that the relevant frame of reference for judging their actions is the LOAC, not peacetime criminal law.

In such a case, the rebels might be granted, in effect, the legal privilege of attacking those designated 'enemy' combatants with impunity. But, if so, it would be justified by the pragmatic goal of encouraging more discriminate fighting, not because the rebels have a first-order moral claim to recognition. The concession is made, in effect, because other parties are, in a sense, over a barrel and not because the rebels are morally or politically legitimate. As an example, militias from the Bosnian Serbs in Bosnia during the civil war were treated as legal equals of the Bosnian regular forces. This helped legitimate the UK's decision not to intervene by allowing it to claim a duty to remain neutral between opposing sides, a position that has since been criticized on moral grounds since the Bosnia Serbs were fighting for unjustifiable ethno-political goals and committed crimes against humanity (Simms 2002).

Rather than providing clear and morally defensible criteria by which to determine whether rebels can claim recognition as legitimate belligerents, the LOAC thus draws an uncertain series of lines, each bisecting the categories of both just and unjust rebellions. As a normative frame of reference, therefore, it cannot serve comprehensively the needs of third parties trying to frame judgments about the status of actions by rebels. Whether the killing of a soldier, for example, ought to be evaluated positively as a discriminate attack, permissible within the LOAC, or condemned as murder depends on a prior judgment about which normative frame of reference is appropriate to the case and, hence, which description of the same action is the appropriate one: is it an act of war or merely a warlike act in peacetime? ${ }^{5}$ This, in turn, depends either on the conflicting and uncertain criteria by which those viewing the case purely from a legal perspective might make such decisions or on those of just war theory and its applications to rebellion. Already, therefore, it is possible to see why a further, third normative perspective, distinct from the legal and the more narrowly moral, is needed from which to decide which line of reasoning to follow.

\subsection{Illegal but Justified Methods}

The obverse side of Ohlin's functional criteria of belligerency is that if rebels, for instance, wear civilian clothing and fight without visible insignia, then they cannot claim combatant privileges and their opponents are not obliged to grant them the rights of warriors upon capture. But what if the state failed to honour its obligations, refusing to recognize legitimate rebels and ordering its soldiers to violate IHL?

\footnotetext{
5 As Ignatieff writes, there is a choice 'between two competing moral frames of reference, and we have to understand what moral frame of reference we are in, and in what situation' $(2002,1155)$.
} 
I have argued elsewhere that, in those circumstances, legitimate rebels with just cause might be released from some obligations set out in the LOAC (Finlay 2015). 'Perfidious' methods, for instance, as defined in the LOAC include the use of civilian disguise to sneak up on enemy soldiers and attack while their guard is down. Critics raise two moral objections. First, it makes discriminate, proportionate warfare by the opposing side more difficult and increases the rate of erroneous and collateral harms to non-combatants. As such, it wrongs the civilian members of the population who are supposedly benefiting from rebellion. The second objection is that it is unfair to enemy soldiers: it exploits their good faith adherence to NCI to trick them into lowering their guard or failing to take measures necessary to defend themselves (Meisels 2008 uses both arguments; cf. Walzer 1977, 176-79; Zohar 2004, 734 n. 2).

Both objections are subject to challenge, however, in at least some imaginable cases of justified rebellion. As regards the ambient civilian population, just as some members of a people in revolt might discount their own safety and willingly expose themselves to the enormous risks of joining in the fight, so too might others be willing to endure a lesser increased risk to themselves by facilitating combatants in hiding from enemy attack. It all depends, as I have argued, on the degree of support there is for the rebels and the extent to which members of the wider population are willing to take on a greater share of those risks (Finlay 2013, 2015, Chapters 7 and 8). Another argument that might support the practice in some cases is based on the justification for conscription: if it is conceivably justifiable to conscript some members of the population as combatants, as it might be, then it might also be justifiable - a fortiori-to impose lesser risks to help support partisans fighting on their behalf (Finlay 2013, 2015; Fabre 2012). This is all supposing that such tactics may be necessary in some circumstances for a reasonable chance of success and that the injustices against which rebels fight are of the most severe kinds.

Enemy combatants are wronged by these tactics, I have suggested, if their good faith in respecting NCI is exploited. But if this is what grounds a prohibition on using them in some instances, then in cases where regular soldiers are not willing to respect the LOAC the moral grounds for complaint don't apply. If so, then it is because the moral prohibition on perfidious means is predicated on reciprocity. It might be objected, of course, that if the enemy doesn't regard civilians as immune, then the tactic won't have the desired effect. But, even when faced with an enemy that fights without restraint, feigning the appearance of someone unthreatening might help give the element of surprise.

Mark Osiel has argued that 'the reciprocity principle is well embedded [in IHL] and, as generally understood, cannot support a policy of restraint in fighting Al Qaeda or similar militant jihadists' that disregard its provisions. Critics wishing to challenge justifications offered for practices like torture and assassination must find grounds other than law, which is easier in some cases than others. Osiel finds grounds in an interpretation of what he calls 'diffuse' reciprocity that is more nuanced than the 'tit-for-tat' variety that is commonly understood to apply in war and some other practices. He argues that the US might be obligated by the terms of IHL even when fighting enemies like Al Qaeda because of its role in upholding multilateral reciprocity more widely across the globe and in spite of the fact that its immediate opponents flout the rules. This argument might conceivably be cited by way of an objection to my claims about rebel forces, but I think it is unlikely to apply to the cases I'm concerned with. As powerful as Osiel's argument may be when speaking of makers and breakers of global order like the US, they would be less persuasive regarding rebels. The behaviour of irregular insurgents is less likely to have an immediate effect on the practices of states generally. And the uncertainty of avoiding outright defeat in revolutionary war will mean that the urgency of adopting any means that might help leverage 
forces is likely to be much higher for rebels than for powerhouses like the US military. The claim that diffuse reciprocity might have on rebels is therefore relatively weak and the appropriate notion to apply is more likely to be that of tit-for-tat (see Osiel 2009, 7 et passim).

So it seems possible to argue that 'perfidious' methods prohibited by the LOAC might nevertheless be morally justifiable in some imaginable circumstances. But the idea that parts of the LOAC are sometimes binding only if reciprocated arises also in relation to the immunity of civilians. Consider the following case:

(4) Terrorist State Rebels have just cause against the government in Terrorist State and, indeed, the need to defeat the incumbent regime is gravely urgent due to its violently oppressive nature. The government refuses to recognize the rebels in spite of their moral legitimacy and willingness to comply with the laws of war. Moreover, in order to defeat the revolt, state soldiers will disregard not only the rights of captured enemies but also NCI.

Imagine that in Terrorist State the regime depends for its survival not only on its combat soldiers but also on a large-scale governmental administrative apparatus operated by officials who manage internal security as well as other functions. These include transport services (used both by civilians and military logistics), police (used both to fight ordinary crimes and to suppress domestic opposition to the government), and many other things beneficial to those civilians protected by the regime and to the regime's survival. Officials are often members of the ruling party or at least sympathize with it.

In spite of their civilian status, therefore, many individuals in this state who are strictly speaking 'non-combatants' are also (a) important causal contributors to the effective functioning of a brutally violent regime, (b) conscious of this fact, and (c) content or even eager to help secure its aims. Moreover, (d) insofar as the soldiers who threaten rebels with violent suppression are acting on their behalf, these civilians may be vicariously liable to share the harms necessary for the rebels to defeat them (for this idea, see Tadros 2014). Hence, (e) we may say that they share moral responsibility for the regime's survival and the aims it violently pursues. I take it that this is not a wholly unrealistic characterization of how oppressive political regimes might sometimes function. The question is: to what extent would the principle of NCI be morally binding on people who rebel against them?

My assumption is that the bindingness of NCI is grounded in part in its ability to guide combatants away from attacking those not morally liable to bear the harshest costs of the conflict (see, e.g., Haque (2014)). If so, then in at least some cases resembling Terrorist State the duty to abide strictly by this component of the LOAC is moot. I think it is arguable that, once they had satisfied some further conditions, the rebels could justifiably set aside NCI as such as the central guideline for discriminating between liable and nonliable targets and follow, instead, a modified principle that tracks moral responsibility more directly. On this basis, attacks might justifiably be directed at a range of people that could include, for instance, civilian political leaders, senior functionaries in government, members of police and civilian security forces, and maybe others who play a significant part supporting the regime (cf. Wilkins 1992). Applying this modified principle of discrimination would be justifiable on the additional conditions that, first, doing so was proportionate as a whole and, second, necessary. By 'necessary,' I mean that it would be at least as proportionate in terms of the numbers of morally innocent casualties expected on this strategy as on the most proportionate alternative. Where it was only equally proportionate, it would need to have a higher prospect of success. Estimates of innocent casualties should include both those that can be expected by the continued survival of the regime, side-effect 
casualties caused by rebel arms, and innocent casualties expected to arise from enemy resistance. $^{6}$

Judgments about individual moral liability to attack ought not, Haque argues, to be left to soldiers to decide, on a target by target basis. Much more likely to achieve the desired effect of minimizing harm to those least liable is to have them follow a simpler, clearer procedural guide (Haque 2014). In most cases, perhaps, NCI can serve this purpose. But, in a rebellion in which the behaviour of state soldiers rendered NCI moot, a competent rebel leadership might alternatively designate some categories of non-combatants legitimate targets thereby specifying an amended guideline for their partisans to follow. This would be justifiable if their professional contribution within government or security was sufficiently strategically important to make it necessary to negate it and to make its members deeply complicit in the injustices against which the rebels are fighting. ${ }^{7}$ The application of any such rule would have to respond to a careful analysis of the nature of the regime and the people it employs. Those who contribute involuntarily are less likely to bear sufficient moral responsibility for participation than those who choose their roles and will therefore remain immune. Likewise, those whose contribution serves important legitimate purposes overlapping with those of the regime are to that extent less likely to be morally legitimate targets. And, however the revised principle of discrimination was configured, rebels adopting it ought to make their targets aware that their role in the regime has been deemed important enough to merit attack (Finlay 2015, 224-5).

If civilians may sometimes be identified as legitimate targets in this way, then it is on the basis of moral liability arising from their participation in a state-led conspiracy to murder. Waldron might object to this argument that, ' $[\mathrm{t}]$ here is no general moral permission to kill those who are guilty of injustice' $(2010,108)$. He maintains that any killing that is not a defensive response to 'the most imminent deadly threats' or privileged as a legitimate attack by the LOAC, is murder by default. Civilians who engage directly in the violence of armed conflict may be liable to harm under either heading, potentially. But, otherwise, killing them remains subject to the usual principle and is regarded simply as murder (Waldron 2010, 107; for similar analysis, Fletcher 2002, 57-9). As a statement about guilt this is, of course, quite right but it doesn't capture the relevant intuitions. Killing is not, on the argument I have set out, a retributive end in itself. Rather, my claim is that sometimes civilians might knowingly contribute to a wrongful threat in causally significant ways and, as such, might be liable to attack alongside those who prosecute it directly in combat roles. Liability to harm in this way occurs, as Jeff McMahan maintains, only if harming them is necessary to defend against the threat (McMahan 2009, 8). But, whereas McMahan suggests that civilian liability could only arise as a very unusual exception, my view is that civilian moral liability might be more usual in justified armed rebellion due to the nature of the regimes most apt to trigger it and the difficulty of fighting them successfully by conventional means (cf. Finlay 2015, Chapters 4 and 8).

One other practice that might seem like a permissible exception to strict adherence to the LOAC in revolutionary conflicts is the infliction of violent harms on innocent noncombatants in extremis - 'terrorism' in a strict sense (on some accounts, e.g., Zohar 2004, 734-5; McMahan 2009, 232). Even though terrorist attacks in this sense are uncontroversially mala in se, many authors discuss hypothetical cases where they might be justifiable [classically, Walzer (1977) but also Held (1991), and Wilkins (1992)]. My view is

\footnotetext{
${ }^{6}$ For detailed analysis and defence of this idea, see Finlay (2015), Chapters 5 and 8.

7 Finlay (2015) on 'prosopographical targeting'; cf. Walzer (1977) on the 'political code'.
} 
that, although hypothetical justifications are imaginable (Finlay 2015, Chapter 9), they wouldn't greatly contribute to the strain between morality and law. True exceptions, first of all, are too empirically improbable. The best argument for entertaining them in philosophy is to clarify the demandingness of exceptions in order to prove the forcefulness of the rule. And even if exceptions are possible, secondly, then they present as conflicts as much within morality as between morality and other principles. It may even be right to see them as 'dirty hands' cases in which agents committing the offence ought to be seen as excused by circumstances rather than justified by their aims (on which, see Walzer 1973).

\section{Hard Norms Versus Soft Norms}

The view I have outlined in Sect. 2 contrasts sharply with the one Michael Walzer outlines in Just and Unjust Wars. He adheres to what we might call a 'syncretistic' view in which deeper conflicts between morality and the LOAC can generally be resolved in favour of the latter. Both, Walzer argues, are the articulations of a singular 'war convention' developed through centuries of ongoing debate and practical adaptation (Walzer 1977, 44). The jus in bello that emerged in modern just war theory runs more or less in parallel with the principles governing discrimination, proportionality, and collateral damage in contemporary international law and agrees with its egalitarian structures. The consensus that Walzer sought to express and reinforce, however, is now much more doubtful and the pre-eminence of law has had to be defended repeatedly against philosophers whose analysis of the morality of war often pulls sharply against it. I review briefly some reactions to the emergence of deep tensions in the first part of this section (Sect. 3.1) before pulling back in favour of morality against one of the most striking attempts to subordinate it to law, Waldron's (3.2). In the final section (Sect. 4), I conclude that the impossibility of resolving the tension in a conclusive, universal way points to the existence of an inescapable political dimension to normative theory, one that comes into view when it is necessary to mediate between law and morality.

\subsection{The LOAC and the Just War Idea}

In a series of writings published between the 1920s and the early 1960s, the German jurist, Carl Schmitt, argued that the integrity of European public international law was profoundly threatened by two related developments. First was the revival of the just war idea, what he called the 'Discriminating Concept of War' (Schmitt 1937; also 1932). The second was the growing prevalence of partisan war and a tendency to recognize it as having moral justification within the framework of revolutionary ideology (Schmitt 1962/2007). Indeed, the latter was a descendent of the former insofar as rebels might thus be seen as engaged in a form of just war when fighting wrongful occupation, colonialism, or domestic tyranny. These twin developments compromised the ability of the legal conventions through which the modern 'bracketed' notion of war was constructed to 'humanize' war by inhibiting its tendency to escalate and expand temporally and spatially (Schmitt 1950/2003, 152).

In many ways, the more recent divergence between revisionist just war theory and the post-war LOAC bears out Schmitt's conclusions. The discriminating concept of war, he maintained, challenged the assumption that opposing belligerents were sovereign equals with identical rights and responsibilities. Absent the legal convention of treating both sides as if they had an equal right to fight as a whole, the immediate danger arose that individuals 
would be held accountable according to different standards. It would depend on whether they contributed to what was seen as a just or an unjust war. If belligerent powers came to see themselves as engaging in war for the sake of justice and against those (by hypothesis) opposing it, then it would tempt them to dehumanize their enemies and to disregard legal restraints in pursuing victory. The recognition of irregular, rebel forces undermined the classical concept of war by removing one of its brackets directly: instead of treating war as a formal, legal condition triggered by declaration of hostilities between sovereign states, recognizing wars involving non-state parties meant that war might occur in any circumstances where it was thought either that rebels had just cause, morally speaking, or where the material fact of warlike acts created a de facto state of war. In either case, it challenged the sovereignty of the state and the authority of governments, bringing their political existence into question as soon as they faced armed internal opposition.

Schmitt's diagnosis suggests a first reaction that we might try to take to the tension between the LOAC and the morality of rebellion: subordinate the latter to the former, suppressing the conclusions of just war moral analysis where they conflict with the law and the states system it is premised on. This seems unsatisfactory, however. It would demand that lawyers and nonlawyers alike bury their heads in the sand in order to ignore both the philosophical and the historical developments of the past number of decades. Philosophically, the theory of the just war has enjoyed a continued revival since Schmitt wrote about its legal consequences. And, historically, the Discriminating Concept of War is arguably too deeply entrenched in international law to ignore, given its echoes in the United Nations Charter, in the recognition of rights of self-determination, and more recently in the emerging norms of the Responsibility to Protect. These recognize not only the wrongfulness of waging wars without moral justification but also the possibility that war might be legitimate when faced with international aggression as well as crimes against humanity, war crimes, and genocide. The just war genie is well and truly out of the bottle (Neff 2005, Section IV).

If the first possibility for addressing conflict between law and morality was a Schmittian legalism, the alternative might be a moralism in which the question of law is set aside entirely in favour of a purely moral analysis of the rights and wrongs of war. What it might give rise to is suggested by Cécile Fabre's account of 'cosmopolitan' just war theory. Fabre restricts her focus to 'the moral principles that should guide our resort to and conduct in war' and brackets the question of whether the current LOAC ought to be changed or remain the same $(2012,12)$. It is not entirely clear whether she thinks that her account of the 'first-best' morality of war ought ever to be followed directly even by those with just cause. But it illustrates what might happen if we did follow a purely moralistic account of the ethics of armed conflict.

As a revisionist, Fabre believes those who lack a just cause simply have no moral right to fight. By contrast, those with a just cause grounded in cosmopolitan principles sometimes enjoy moral permissions that greatly exceed those that would be granted under the LOAC. If abiding by the law would condemn them to defeat from the outset, irregular soldiers fighting an asymmetric war against militarily superior enemies might be permitted the use not only of civilian disguise, but also the coercive use of civilian shields and, in truly extreme cases and against genocidal enemies, terrorist attacks against innocent civilians (Fabre 2012, Chapter 7). The chief determinants of whether such tactics are ever justified are (a) the justice of the cause being pursued, (b) the degree to which adhering to the rules is likely to compromise efforts to secure it, and (c) the overall proportionality of adopting such legally prohibited methods. If the latter exceeds a certain threshold, then the benefits of fighting in this way countervail against its pro tanto wrongfulness and it may be justified. 
While it will be evident that I am sympathetic to the idea that legal rules might be overridden for moral reasons in certain circumstances, it is clear that a theory built on this sort of purely moral analysis couldn't claim hegemony over the entire normative field of armed conflict. As Fabre herself writes, 'a full normative account of war should not merely delineate first-best principles for war, but also (morally directed) second-best principles which can be enshrined in the law' $(2012,12)$. One way in which the more purely moral perspective might be maintained while doing this is through legal revisionism, a thought pursued at different times by both David Rodin and Jeff McMahan. Eventually, both have suggested, it might be possible to harmonize law with (deep) morality to a greater extent than is now the case. Rodin envisages global political reforms, for instance, within which the current principle of national defence would be replaced by something closer to global policing under international law (2002). McMahan speculates about the potential to use an international court to arbitrate over the justice of particular wars and, hence, to advise soldiers as to whether they should fight or defy orders to do so $(2008,41-3)$.

If the just war idea cannot itself be suppressed in favour of an egalitarian, formalist international law of armed conflict, and if, moreover, it is not likely-as revisionists acknowledge - that the LOAC will be radically altered in the immediately foreseeable future, then we are still left with a problem. How should the normative consequences of the Rebel Principle that I mapped out in Sect. 2 be managed?

I now turn to Waldron's claims about the force of NCI and his argument that, as a 'deadly serious convention,' it cannot be overridden by the claims that revisionists like McMahan make on the basis of the 'deep' morality of war. Were he right, it could partially solve the problem by placing law prior to morality and eliminating exceptions of the sort I outlined in Sect. 2.2.

\subsection{Deadly Serious Conventions; Deadly Serious Causes}

Waldron's argument (2010) is that NCI is binding on combatants in all circumstances ${ }^{8}$ : even if there were cases where the culpability of civilians was sufficient to bring their moral immunity into question, he argues; and even if, per McMahan's analysis of the deep morality of war, the principle of NCI ought to be interpreted as defining mala prohibita rather than reflecting deeper convictions about mala in se; the legal obligation to respect the immunity of non-combatants and eschew terrorist methods is 'deadly serious' in a way that makes violating it a profound moral wrong. Deadly seriousness is identified with 'its responsiveness to an important underlying reason, namely the mitigation of the savageries of war, and [...] the consequences of [...] violation.' If 'powerful entities' undertake 'sustained violations as a matter of policy,' Waldron argues, then it jeopardizes the 'collective good' at which the convention aims by threatening to overturn a practice whose roots are shallow and which is always precarious in international politics. Relatively few states or 'armed organizations' have 'military doctrines' and the temptation to abandon them in favour of unrestricted warfare will grow with the rate of non-compliance by these powerful entities $(2010,105)$.

If correct, then Waldron's analysis would resolve conflicts in favour of law in cases where a more purely moral analysis might propose breaking it. I think, however, that it pays insufficient attention to the precise nature of the tensions arising between morality and

\footnotetext{
${ }^{8}$ Waldron doubts the assumption that moral guilt or responsibility for things like unjust war can render civilians morally liable to killing in any case; he merely grants for the sake of argument the possibility of tensions between law and morality of the sort discussed in the argument I engage with in Sect. 3.2.
} 
law. These vary according to the deontological status of the action considered from each perspective and the kind of solution that we ought to prescribe most likely varies with the tension too. Setting aside cases where morality and law simply agree regarding a particular type of action, $x$, the following all remain possible:

(1) Moral permission; legal prohibition.

(2) Moral justification; legal prohibition.

(3) Moral prohibition; legal permission. ${ }^{9}$

(4) Moral duty; legal prohibition.

(5) Moral prohibition; legal duty.

(6) Moral prohibition; legal justification.

In cases that have the characteristics of (1), a law that was morally justified on the whole would trump what morality might otherwise have permitted as regards $x$. Insofar as morality might say that whether an agent performed or forbore from $x$ was not wrong in itself and that, therefore, doing $x$ was morally a matter of indifference in the absence of a legal prohibition, the legal view that doing $x$ is wrong would prevail.

Contrariwise, in cases like (3), morality presumably trumps legality, all else being equal. You ought not to do something that is immoral, that is to say, even if it is not prohibited by law. How forceful the injunction against such actions is varies depending on the nature of the moral wrong. Think, for instance, of infidelity between spouses or lovers which might be frowned upon morally in a secular democracy but is not legally prohibited. Compare that sort of case with the predicament of someone conscripted by a sovereign state to fight in what they believe to be an unjust war, which is also a case of (3).

By contrast, cases that have the characteristics of (4) and (5) are much less clear. While we might generally think there are reasons to let the law prevail in such contests, we really do need to know a lot more about the reasons for the duties and prohibitions on both sides before we can make any confident pronouncements on a particular case. Finally, cases like (2) are also hard to be confident about in the abstract. On the face of it, they seem like cases of (1) but it depends on the nature of the justification. Weaker justifications might resemble permissions; stronger ones might run closer to duties and, hence, might obligate to some degree. The question is: which types of tension are typical of the cases that we have to think about in the normative theory of war?

My suspicion is that the degree to which morality and law can conflict in such cases has been underplayed at times due to an implicit miscategorization of the tensions. Whereas philosophers treat them as cases like (1), they would turn out, if scrutinized more carefully, to be cases of (4). The reason for this is as follows. Properly understood, just war theory sees the resort to armed force as permissible only in circumstances where it is justified. It is

\footnotetext{
${ }^{9}$ It might be objected by international lawyers, Alejandro Chehtman suggests (personal communication), that killing in war isn't permitted as such; rather, the law 'confers on [individuals] an immunity from punishment or other legal consequences.' I agree that the status of wartime killing is ambiguous but believe it is nevertheless accurate to characterize the upshot of some authoritative legal sources as amounting to a 'permission.' For instance, according to the International Committee of the Red Cross Commentary on the Additional Protocols, article 43 of Additional Protocol 1 sought to eliminate some of the ambiguity in the Third Geneva Convention on precisely this head, writing that, '[t]he Conference considered [...] that it should be explicitly stated that all members of the armed forces [with the exception of medical and religious personnel] can participate directly in hostilities, i.e., attack and be attacked' (Sandoz et al. 1987, 515). Consequently, article 43.2 of Additional Protocol 1 states: 'Members of the armed forces of a Party to a conflict $[. .$.$] are combatants, that is to say, they have the right to participate directly in hostilities.' The$ ambiguity between permitting and not punishing comes out most forcefully when the law and morality are considered together. See, for example, Janina Dill and Henry Shue (2012, 319).
} 
not a matter of whimsical discretion; matters of grave moral importance must be at stake. And, uncontroversially, armed force is justified in this sense only where there is something at stake that is of such grave moral importance that it can sanction the resort to force. ${ }^{10}$ Such, in fact, would the gravity of a cause have to be before it would be sufficiently important to warrant a resort to war that we would be as justified in calling it a 'deadly serious cause' as Waldron is in calling NCI a 'deadly serious convention.' Deadly serious causes are those that provide reasons for resorting to force that are sufficiently weighty to countervail against the reasons that usually prohibit (large-scale, organized) killing; the only reasons weighty enough to do so, I submit, are duties (not mere preferences or whims). The emphasis that theorists of justified war almost invariably place on 'necessity,' however interpreted, reflects this thought: you can only justify a resort to the lethality of war if you have to.

In just war theory, therefore, can implies ought, so to speak, to reverse Kant's maxim, since the permission to commit to such an extreme course of action could only arise following an obligation. There is, however, a partial caveat to this claim. Not only must the cause of war be deadly serious but the chance of success and the balance of relevant risks and costs versus expected gains it aims at (discounted for probability) must be auspicious enough to make it worth the perils of pursuing it. Such prudential constraints on justification, however, might conceivably render two alternative courses of action, one involving arms and the other not, equally proportionate or nearly so (where Proportionality compares their respective gains with doing nothing at all). And even if we adopted an ad bellum condition of Necessity, according to which war was justified only if it could demonstrate significant net advantages in the balance when compared with alternative courses of action, the two rival strategies could still turn out to be justifiable to a roughly equal degree given the right balance of risks and costs arising from each. This caveat, however, doesn't constitute an objection to the basic claim about deadly serious causes. In a case where war and an alternative strategy both satisfied Proportionality and where war lay on the borderline between satisfying Necessity and not satisfying it, it shouldn't distract from the fact that both options are justifiable with reference to the same deadly serious causes and it is obligatory to choose one of them. Whichever is chosen, it must then be pursued with the same deadly seriousness.

If my reasoning is correct about can implying ought in questions of morally justified violence, then armed conflicts seeming to present just combatants with a conflict of the sort indicated by (1) will turn out on closer scrutiny actually to be cases of (2) and these, in turn, will actually have the same complexion as (4). For rebels to claim just cause to wage war against their rulers they must, by this argument, be able to show that they are responding to an injustice or threat of one that is deadly serious, i.e., weighty enough to warrant such a perilous course of action. Such causes generate obligations not only to fight but also, presumably, to make necessary efforts to win. I suggested in Sect. 2 that some tactics prohibited by the LOAC are likely to be necessary in some cases to maximize chances of success. If this is sometimes true, then methods that violate NCI are sometimes morally obligatory even while they are legally prohibited.

Given the circumstances outlined in the hypothetical cases discussed in Sect. 2, it is arguable that resorting to prohibited tactics could also be reasonable in some instances, given failures to comply with the LOAC by government forces along with the other conditions indicated in Sect. 2.2. In circumstances of that sort, if an alternative to the

${ }^{10}$ On the claim that just wars cannot be a matter of moral discretion, see Oberman (2015); for a divergent view, see Zohar (1996). 
LOAC could be followed by legitimate rebels that satisfied both deep moral commitments to respect the immunity of the innocent and a deadly serious obligation to fight effectively against grievous wrongs and threats to the innocent, then we might invert the formula that Haque offers for justifying the deviations that the LOAC makes from morality: deviation of conduct from the LOAC is justifiable if, by directly following the morality of war rather than the LOAC, combatants will reduce the overall seriousness of the moral wrongs they will inevitably commit (cf. Haque 2014, $86^{11}$ ).

\section{A Political Theory of the Ethics of War}

In contrast to Waldron, my view is therefore that neither type of norm-the moral nor the legal - can entirely dominate across all cases, universally effacing or negating the legitimacy of the other. If a direct clash of the sort characterized above is possible in which a moral duty directly contradicts a legal prohibition, as I have argued, then the deadly seriousness of legal convention cannot on its own account for a uniform practice of settling the conflict in favour of law. Which norm ought to prevail depends on the specificities of the case: which, in the circumstances, is more 'deadly serious,' the cause or the convention? This is why I think neither moral philosophy nor the LOAC can encompass the normative field as a whole. Both have to be accommodated and their mutual relations mediated within a broader political theory of war ethics.

It may very well be true that the right answer will usually be to follow NCI and the LOAC. But if exceptions to this rule are possible, then we need some way of figuring out which is the right approach in each case. This we can do only once we analyze each concretely, evaluating the various moral and political values at stake in it. And if the question of tactics and jus in bello requires a wider normative political perspective capable of mediating between the respective claims of morality and law, so too does the question of recognition. To determine in a normatively satisfying way whether an individual rebel ought to be regarded as a legitimate combatant with the privileges of belligerency in the first place perhaps more immediately raises questions falling within the purview of political theory: concerning, for instance, the degree to which the competence of a warring side depends on such matters as popular preferences, consent, authorization, or representativeness (Finlay 2015, Chapter 6).

Analysis of all these matters ought to be informed by both morality and law but also has to address itself to a concrete specificity that neither is equipped to account for fully. Once we had established, for instance, that rebels were fighting for a cause of the right sort, morally or legally, we need to know how much the goods and rights they aimed to secure were worth to those on whose behalf they fought. How much risk are the members of this group willing to take-personally_in pursuing them? Are they willing to risk their lives for them? Hence, can a rebel group that acts in such a way as to bring about an armed conflict claim to do so in the interests of its putative beneficiaries as those beneficiaries define them? And if the only war with a chance of securing those goals requires irregular methods which distribute those risks widely across the population as a whole, can it claim to have the mandate of those people who will bear that burden in carrying it forward? Determining how best to weigh the competing claims of morality and legality, justice and

${ }^{11}$ Haque writes, by contrast, that 'the deviation of law from morality is justifiable if by directly following the laws of war rather than the morality of war combatants will reduce the overall seriousness of the moral wrongs they will unavoidably commit.' 
law, in light of the answers to questions such as these is a classic problem of practical, political judgment.

For these reasons, to return to the question I raised in the introduction, the normative field of armed conflict is greater than that which the LOAC is able to navigate solo. Not only is it necessary to take account of deep moral theory and the moral perspective of just war theory, it is also necessary to negotiate their relationships with law by reflecting on the political dimensions of conflict in concrete cases. An adequate normative framework for thinking about and engaging in public debate concerning the wrongs of terrorism and the rights of rebels cannot, therefore, be limited to the framework of the LOAC and the category of War Crimes. But nor can it rely entirely on moral theory and its direct application to armed conflict. What we need is a three-dimensioned account that takes legal, moral, and political judgments into consideration. Only in this way can we provide a sufficiently principled, comprehensive, and supple framework for public-political debate about the ethics of contemporary political violence.

Open Access This article is distributed under the terms of the Creative Commons Attribution 4.0 International License (http://creativecommons.org/licenses/by/4.0/), which permits unrestricted use, distribution, and reproduction in any medium, provided you give appropriate credit to the original author(s) and the source, provide a link to the Creative Commons license, and indicate if changes were made.

\section{References}

Biggar, N (2013) 'Christian Just War Reasoning and Two Cases of Rebellion: Ireland 1916-1921 and Syria 2011-Present,' Ethics and International Affairs 27.4: 393-400.

Buchanan, A (2013) 'The Ethics of Revolution and Its Implications for the Ethics of Intervention,' Philosophy and Public Affairs 41.4: 292-323.

Cullen, A (2010) The Concept of Non-International Armed Conflict in International Humanitarian Law. Cambridge: Cambridge University Press.

Dill, J, and H Shue (2012) 'Limiting the Killing in War: Military Necessity and the St Petersburg Assumption,' Ethics and International Affairs 26.3: 311-33.

Dobos, N (2011) Insurrection and Intervention: The Two Faces of Sovereignty. Cambridge: Cambridge University Press.

Doyle, M (2015) The Question of Intervention: John Stuart Mill and the Responsibility to Protect. New Haven: Yale University Press.

Draper, K (2016) War and Individual Rights: The Foundations of Just War Theory. New York: Oxford University Press.

Fabre, C (2012) Cosmopolitan War. Oxford: Oxford University Press.

Finlay, C (2013) 'Fairness and Liability in the Just War: Combatants, Non-Combatants, and Lawful Irregulars,' Political Studies 61.1: 142-60.

Finlay, C (2015) Terrorism and the Right to Resist: a Theory of Just Revolutionary War. Cambridge: Cambridge University Press.

Finlay, C (2017) 'The Perspective of the Rebel: a Gap in the Global Normative Architecture,' Ethics and International Affairs 31.2: 213-34.

Fletcher, G (2002) Romantics at War: Glory and Guilt in the Age of Terrorism. Princeton: Princeton University Press.

Haque, A (2014) 'Law and Morality at War,' Criminal Law and Philosophy, 8.1: 79-97.

Held, V (1991) 'Terrorism, Rights and Political Goals,' in RG Frey and CW Morris (eds.) Violence, Terrorism and Justice. Cambridge: Cambridge University Press: 55-84.

Ignatieff, M (2002) 'Human Rights, the Laws of War, and Terrorism,' Social Research 69.4: 1137-58.

Kennedy, D (2006) Of Law and War. Princeton NJ: Princeton University Press.

McMahan, J (2008) 'The Morality of War and the Law of War,' in D Rodin and H Shue (eds.) Just and Unjust Warriors: the Moral and Legal Status of Soldiers. Oxford: Oxford University Press: 19-43.

McMahan, J (2009) Killing in War. Oxford: Oxford University Press. 
Meisels, T (2008) The Trouble with Terror: Liberty, Security and the Response to Terrorism. Cambridge: Cambridge University Press.

Neff, S (2005) War and the Law of Nations: a General History. Cambridge: Cambridge University Press.

Oberman, K (2015) 'The Myth of the Optional War: Why States are Required to Wage the Wars they are Permitted to Wage,' Philosophy and Public Affairs 43.4: 255-86.

Ohlin, JD (2015) 'The Combatant's Privilege in Asymmetric and Covert Conflicts,' Yale Journal of International Law 40: 337-93.

Osiel, M (2009) The End of Reciprocity: Terror, Torture, and the LOAC. New York: Cambridge University Press.

Rodin, D (2002) War and Self-Defense. Oxford: Oxford University Press.

Rogers, A (2012) Law on the Battlefield, third edition. Manchester: Manchester University Press.

Sandoz, Y, C Swinarski, and B Zimmermann (eds.) (1987) International Committee of the Red Cross: Commentary on the Additional Protocols of 8 June 1977 to the Geneva Conventions of 12 August 1949. Leiden: Martinus Nijhoff Publishers.

Schmitt, C (1932) 'The Concept of the Political,' in G Schwab and T Strong (eds) (2007) The Concept of the Political: Expanded Edition. Chicago: University of Chicago Press: 19-79.

Schmitt, C (1937) 'The Turn Towards the Discriminating Concept of War,' in T Nunan (ed.) (2011) Writings on War. Cambridge: Polity Press.

Schmitt, C (1950/2003) The Nomos of the Earth in the International Law of the Jus Publicum Europaeum, tr. GL Ulmen. New York: Telos Press Publishing.

Schmitt, C (1962/2007) Theory of the Partisan, tr. GL Ulmen. New York: Telos Press Publishing.

Simms, B (2002) Unfinest Hour: Britain and the Destruction of Bosnia. London: Penguin.

Solis, B (2010) The Law of Armed Conflict: International Humanitarian Law in War, Cambridge: Cambridge University Press.

Tadros, V (2014) 'Orwell's Battle with Brittain: Vicarious Liability for Unjust Aggression,' Philosophy and Public Affairs 42.1: 42-77.

Waldron, J (2010) 'Civilians, Terrorism, and Deadly Serious Conventions,' in Torture, Terror and TradeOffs: Philosophy for the Whitehouse. Oxford: Oxford University Press: 80-110.

Walzer, M (1973) 'Political Action: the Problem of Dirty Hands,' Philosophy and Public Affairs 2.2: 160-80.

Walzer, M (1977) Just and Unjust Wars: A Moral Argument with Historical Illustrations. New York: Basic Books.

Wilkins, BT (1992) Terrorism and Collective Responsibility. London: Routledge.

Zohar, N (1996) 'Can a War be Morally “Optional”?' Journal of Political Philosophy 4.3: 229-41.

Zohar, N (2004) 'Innocence and Complex Threats: Upholding the War Ethic and the Condemnation of Terrorism,' Ethics 114: 734-51. 